\title{
Pergeseran Bentuk dan Makna Terjemahan dalam Cerpen Kappa Karya Akutagawa Ryunosuke
}

\author{
Ni Putu Ayu Krisna \\ Program Studi Sastra Jepang Fakultas Ilmu Budaya \\ [iina_14@ymail.com]
}

\begin{abstract}
This research focuses on the analysis of shifting in form and meaning of short story entitled Kappa from Japanese into indonesian. The purpose of this research is to know the translation in form and meaning and also the technique used by the translator in the alignment of the form and the meaning of the source in the context of the target. The data in this research are all words and sentences in Kappa short story by Akutagawa Ryunosuke and its translation in Indonesian with the same title translated by Winarta Adisubrata.The data were collected by referring method and technique of record, after that to analyze the data using method of translational pad with glossing technique then continued with formal and informal method in presenting the data. The theory used in this research are Catford shape shift theory (1965), theory of component analysis of meaning of Bell (1993) and technique theory of translation of Molina and Albir (2002). The result of this research shows that there are from 72 data of word class shift there are 24 data shift of verbs, 10 data shift of adjective, 27 data shift of adverb and 11 data shifting of noun and there are 10 data of meaning shift. The most widely used translation technique is literal translation technique.
\end{abstract}

Keywords: translation, shifting form, shifting meaning

\begin{abstract}
Abstrak
Penelitian ini berfokus pada penganalisisan pergeseran bentuk dan makna dalam penerjemahan cerpen Kappa dari bahasa Jepang ke bahasa Indonesia. Adapun tujuan dari penelitian ini ialah untuk mengetahui pergeseran bentuk dan makna dari bahasa sumber ke dalam bahasa sasaran serta teknik penerjemahan yang digunakan untuk menjaga kesepadanan bentuk dan makna dari bahasa sumber ke dalam bahasa sasaran. Data dalam penelitian ini adalah seluruh kata dan kalimat pada cerpen Kappa karya Akutagawa Ryunosuke serta cerpen terjemahannya dalam bahasa Indonesia dengan judul sama yang diterjemahkan oleh Winarta Adisubrata. Pengumpulan data dilakukan dengan metode simak dan teknik catat, setelah itu untuk menganalisis data digunakan metode padan translasional dengan teknik glossing kemudian dilanjutkan dengan metode formal dan informal dalam penyajian data. Teori yang digunakan dalam penelitian ini yaitu teori pergeseran bentuk Catford (1965), teori analisis komponen makna Bell (1993) serta teori teknik penerjemahan Molina dan Albir (2002). Hasil dari penelitian ini menunjukkan bahwa dari 72 data pergeseran bentuk kelas kata yang terdiri dari 24 data pergeseran verba, 10 data pergeseran adjektiva, 27 data pergeseran adverbia dan 11 data pergeseran nomina serta terdapat 10 data pergeseran makna. Teknik penerjemahan yang paling banyak digunakan dalam menerjemahkan cerpen Kappa karya Akutagawa Ryunosuke adalah teknik penerjemahan harfiah.
\end{abstract}

Kata kunci: penerjemahan, pergeseran bentuk, pergeseran makna 


\section{Latar Belakang}

Bahasa merupakan bagian yang tidak dapat terpisahkan dari budaya penuturnya. Perbedaan kebudayaan yang terjadi terlihat jelas pada perbedaan kosakata yang digunakan. Setiap bahasa memiliki kosakata yang mencerminkan kekhasan budaya penuturnya yang belum tentu dimiliki oleh bahasa lain (Simatupang, 1999:56). Dari kekhasan budaya yang tercermin dalam kosakata justru menjadi permasalahanterutama ketika mencari padanan. Permasalahan yang sering dihadapi oleh penerjemah adalah cara menemukan padanan atau kata yang sesuai untuk benda dan kejadian yang tidak dikenal dalam kebudayaan sasaran.

Namun dalam menemukan padanan yang sesuai, dalam proses penerjemahan sering menghasilkan hasil terjemahan yang berbeda dengan teks sumber (TSu). Hal ini dikarenakan perbedaan aturan yang dimiliki oleh setiap bahasa yang akan menyebabkan terjadinya pergeseran. Pergeseran yang terjadi biasanya terdapat pada tataran kata, frasa, klausa hingga kalimat sehingga dapat menimbulkan kesalahpahaman pengertian yang menyebabkan isi dan makna terjemahan tidak tersampaikan dengan baik ke dalam teks sasaran (TSa). Suatu teks dalam bahasa sumber (BSu) tidak mungkin sepenuhnya diterjemahkan ke dalam bahasa sasaran (BSa) karena proses terjemahan dimulai dari mencari arti kata ke dalam padanannya kemudian dicari bentuk linguistik yang relevan dalam BSu dan BSa.

Menurut Catford (1965:20), penerjemahan berarti mentransfer BSu ke BSa atau penggantian materi tekstual pada BSu ke dalam BSa. Dalam proses penerjemahan, penerjemah selalu berusaha mendapatkan unsur BSa yang sepadan dengan BSu agar dapat mengungkapkan pesan yang sama dalam TSa. Nida dan Taber (1969:12) menyatakan bahwa menerjemahkan adalah menulis kembali teks dari BSu ke dalam BSa dengan menggunakan padanan yang paling mendekati BSu.

Pergeseran yang terjadi dalam proses penerjemahan dapat berupa pergeseran pada tataran bentuk yang meliputi pergeseran pada tataran kata, frasa, klausa, dan kalimat, serta pergeseran pada tataran makna. Selain itu, penerjemahan memiliki kaitan yang sangat erat dengan kebudayaan yang mendasari $\mathrm{BSu}$ dan BSa. Hal ini disebabkan karena bahasa merupakan salah satu penggambaran kebudayaan penutur. Pada dasarnya pergeseran bentuk terjadi karena adanya perbedaan struktur gramatikal dari BSu ke dalam BSa.

$\begin{array}{lrr}\text { Setiap } & \text { melakukan } & \text { proses } \\ \text { penerjemahan, } & \text { biasanya } & \text { seorang } \\ \text { penerjemah akan } & \text { memilih } & \text { salah satu }\end{array}$ komponen kata yang cocok untuk diterjemahkan dari BSu ke dalam BSa, dengan tujuan untuk menciptakan suatu terjemahan yang serupa ketika dibaca atau didengar. Namun, terkadang penerjemah tidak menerjemahkan kata pada sebuah kalimat yang dirasa mengganjal. Oleh karena itu, penerjemah memilih untuk tidak menerjemahkan kata tersebut atau menggantinya dengan kata lain yang maknanya mendekati BSu. Sehingga pembaca atau pendengar dapat memahami penerjemahan tersebut.

Berdasarkan latar belakang tersebut, peneliti tertarik untuk menganalisis pergeseran bentuk dan makna dalam penerjemahan cerpen yang berjudul Kappa karya Akutagawa Ryunosuke secara mendalam pada penelitian yang berjudul "Pergeseran Bentuk dan Makna Terjemahan Dalam Cerpen Kappa Karya Akutagawa Ryunosuke". Teori yang digunakan pada penelitian ini yaitu teori teknik penerjemahan Molina \& Albir (2002), teori pergeseran bentuk Catford (1965) dan teori makna Bell (1993). 


\section{Pokok Permasalahan}

Berdasarkan latar belakang tersebut, dapat dirumuskan permasalahan sebagai berikut :

a. Bagaimanakah pergeseran bentuk kelas kata dalam terjemahan cerpen Kappa karya Akutagawa Ryunosuke?

b. Bagaimanakah pergeseran makna kelas kata dalam terjemahan cerpen Kappa karya Akutagawa Ryunosuke?

\section{Tujuan penelitian}

Adapun tujuan dari penelitian ini yaitu, untuk mengetahui pergeseran bentuk kelas kata dalam dalam penerjemahan cerpen Kappa karya Akutagawa Ryunosuke. Serta untuk mengetahui pergeseran makna kelas kata dalam penerjemahan cerpen Kappa karya Akutagawa Ryunosuke.

\section{Metode Penelitian}

Penelitian ini menggunakan metode kualitatif. Sumber data dikumpulkan dengan menggunakan metode simak dan teknik catat. Dari data-data yang telah dikumpulkan tersebut kemudian dirumuskan masalah yang dikaji. Dalam proses analisis, metode yang digunakan adalah metode padan translasional dan teknik glossing. Kemudian, setelah proses analisis selesai, hasil analisis dipaparkan dengan menggunakan metode formal dan informal.

\section{Hasil dan Pembahasan}

\subsection{Pergeseran Kelas Kata Verba (Doushi) Menjadi Adjektiva}

$\begin{array}{rlll}\text { (1) TSu : 「それ } & \text { は } & \text { 君 } & \text { も } \\ \text { Sore } & \text { wa } & \text { kimi } & \text { mo } \\ \text { Disitu } & \text { TOP } & \text { kamu } & \text { juga }\end{array}$

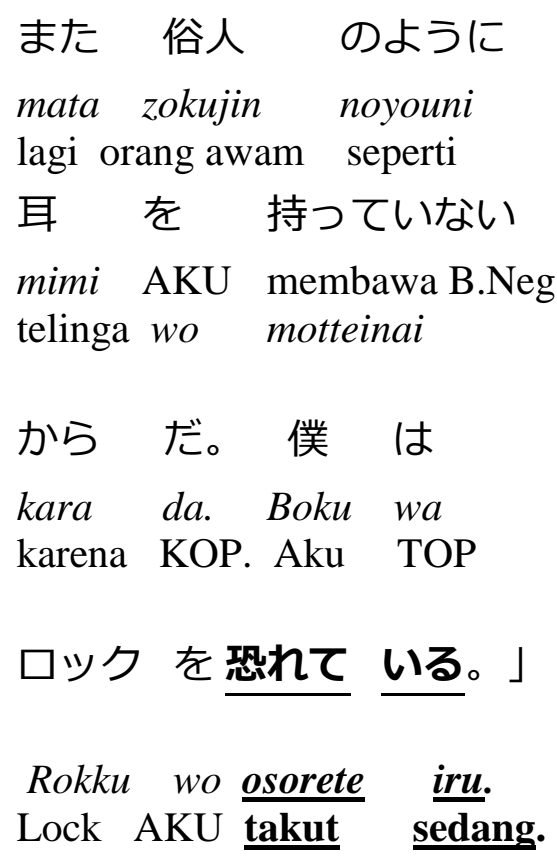

(Kappa, 2007:103)

TSa:“Kau lebih baik dari kappa-kappa yang tak punya telinga untuk musik" katanya dingin "aku takut pada Lock".

(Kappa, 2016:44)

Pada data (1), kata "osoreteiru" termasuk ke dalam kelas kata ichidan doushi yang dapat mengalami perubahan bentuk dari kata dasar osoreru dan mendapat bunsetsu tambahan teiru. Selain itu juga, kata osoreteiru dapat menduduki predikat dalam kalimat. Kelas kata verba yang mengalami pergeseran bentuk kelas kata dari verba menjadi adjektiva, ketika di terjemahkan ke dalam bahasa Indonesia dipadankan dengan kata "takut". Kata osoreru memiliki arti yaitu 'merasa takut; takut; khawatir' (Matsuura, 2014:777). (Matsumura, 1992:148) penjelasan kata osoreru adalah sebagai berikut:

1. 危険などを感じて恐ろしく思う。 こわがる。

2. 悪い結果になるのではないかと心 配する。気づかう。 
1. Kiken nado wo kanjite osoroshiku omou. Kowagaru.

2. Warui kekka ni naru no dewanaika to omoimasu. Kidzukau.

1. Takut karena merasakan bahaya. Menjadi takut.

2. Khawatir karena hasil yang buruk. Merasa khawatir.

Pola teiru merupakan konjugasi

kata kerja yang dalam bahasa Jepang memiliki makna 'sedang melakukan aktivitas'. (Sunagawa, 2005:245) mengartikan teiru adalah sebagai berikut.

$\begin{array}{ll}\text { 〜ている } & \text { : 動作や作用を表す動 } \\ \text { 詞 } & \text { を用いて、その動作・ } \\ & \text { 作用が継続中であるこ } \\ & \text { とを表す。 } \\ \text { 〜eiru } & \text { : Dousa ya sayou wo } \\ & \text { arawasu doushi wo } \\ & \text { mochiite, sono dousa to } \\ & \text { sayou ga keizokuchuu } \\ & \text { dearu koto wo arawasu. } \\ & \text { :Menunjukkan tindakan } \\ \text { teiru } & \text { dan kegiatan yang sedang } \\ & \text { berlangsung, diikuti } \\ & \text { dengan kata kerja yang } \\ & \text { memiliki tindakan atau } \\ & \text { kegiatan tersebut. } \\ \text { Kata } & \text { "takut” memiliki arti }\end{array}$
'merasa gentar (ngeri) menghadapi sesuatu yang dianggap mendatangkan bencana; tidak berani (berbuat, menempuh, menderita)' (Alwi dkk, 2005:1125). Kata "takut" termasuk ke dalam kelas kata adjektiva karena dapat bergabung dengan partikel tidak, mendampingi nomina, atau didampingi partikel seperti lebih, sangat, agak serta dapat menjelaskan keadaan secara spesifik bahwa tokoh merasa gentar (takut) terhadap seseorang yang bernama Lock karena dianggap akan mendatangkan bencana untuknya. Pergeseran bentuk kelas kata pada data tersebut didukung oleh penerapan teknik penerjemahan harfiah yang ditunjukkan dengan menerjemahkan teks kata per kata dan tidak mengalami penambahan atau pengurangan kata dalam TSa sehingga isi pesan dalam TSa dapat tersampaikan.

Berdasarkan analisis pergeseran kelas kata tersebut, diketahui bahwa makna kata "osoreteiru" dan kata "takut" tidak terjadi pergeseran makna. Hal tersebut dapat dilihat berdasarkan tabel berikut ini.

Tabel 1 Analisis Komponen Makna Kata Osoreteiru dan Takut

\begin{tabular}{llcc}
\hline No & \multicolumn{1}{c}{ Makna } & Osoreteiru & Takut \\
\hline 1. & $\begin{array}{l}\text { Gentar } \\
\text { karena } \\
\text { merasakan }\end{array}$ & + & + \\
& $\begin{array}{l}\text { bahaya } \\
\text { 2. }\end{array}$ & & \\
& $\begin{array}{l}\text { Merasa } \\
\text { khawatir } \\
\text { terhadap }\end{array}$ & + & + \\
& $\begin{array}{l}\text { sesuatu } \\
\text { 3idak berani } \\
\text { (berbuat, } \\
\text { menempuh, } \\
\text { menderita) }\end{array}$ & \pm & + \\
\hline
\end{tabular}

Berdasarkan analisis komponen makna pada tabel 1, dari kedua kata osoreteiru dan kata takut memiliki komponen makna 'gentar terhadap sesuatu' dan 'merasa khawatir terhadap sesuatu' memiliki tanda $(+)$ dikarenakan komponen makna 'gentar terhadap sesuatu' dan makna 'merasa khawatir terhadap sesuatu' masing-masing dimiliki oleh kata osoreteiru dan kata takut. Namun pada komponen makna ketiga memiliki tanda $( \pm)$, kata osoreteiru memang pada dasarnya berarti takut, namun bernuansa lebih sempit karena rasa takut yang dialami hanya sebuah perasaan tanpa adanya sebuah tindakan. Sedangkan pada kata takut, komponen makna 'tidak berani (berbuat, menempuh, menderita)' bukan hanya perasaan namun 
terjadi sebuah tindakan. Oleh karena itu, kata osoreteiru dan takut tidak mengalami pergeseran makna dalam penerjemahan.

\subsection{Pergeseran Kelas Kata Adjektiva}

\section{(Keiyoushi) Menjadi Nomina}

(2) TSu : 「じやあ

Jaa

Kalau begitu

のように 暮している

noyouni kurashite iru

seperti hidup sedang

$\begin{array}{llll}\text { の } & \text { 一番 } & \frac{\text { 幸福な }}{\text { no }} \\ \text { ichiban }\end{array}$

koufukuna

$\overline{\text { NOM TOP paling bahagia }}$

$\begin{array}{lll}\text { 訳 } & \text { です } & \text { ね。」 } \\ \text { wake } & \text { desu } & n e . \\ \text { sebab } & \text { KOP } & \text { PAR. }\end{array}$

(Kappa, 2007:85)

TSa : Jadi kalau begitu kau lebih

bahagia daripada kappa lain?.

(Kappa, 2016:26)

Pada data (2), kata "koufukuna" termasuk ke dalam kelas kata adjektiva karena dengan sendirinya dapat membentuk bunsetsu dapat menjadi predikat dalam sebuah kalimat. Dalam konteks kalimat kata koufukuna digunakan untuk menyatakan sifat. Kelas kata adjektiva yang mengalami pergeseran bentuk menjadi kelas kata nomina terletak ditengah kalimat yaitu kata "koufukuna" yang dipadankan dengan kata "bahagia" dalam TSa. Kata "koufukuna" memiliki arti yaitu "bahagia; kebahagiaan; keberuntungan" (Matsuura, 2014:515). (Matsumura,
1992:402) mengartikan kata koufukuna adalah sebagai berikut.

望んでいることがほとんどかなって

しあわせであるさま。心の満ち足り

たさま。さいわい。

Nozondeiru koto ga hotondo kanatte shiawase dearu sama. Kokoro no michitarita sama. Saiwai.

Hal yang membuat (saya) sangat bahagia. Menunjukkan perasaan puas.

Kebahagiaan.

Kata "bahagia" memiliki arti yaitu 'keadaan atau perasaan senang dan tentram (bebas dari segala yang menyusahkan)' (Alwi dkk, 2005:87). Kata "bahagia" termasuk ke dalam kelas kata nomina karena dapat menunjukkan sebuah kejadian. Kalimat tersebut diterjemahkan oleh penerjemah menggunakan teknik partikulasi dengan menggunakan istilah yang lebih khusus dari TSu ke dalam TSa. Hal ini terdapat pada kata "...anata no youni kurashiteiru..." yang diterjemahkan menjadi '...daripada kappa lain' yang menunjukkan bahwa penerjemahan disesuaikan dengan istilah yang lebih khusus untuk dapat dipahami oleh pembaca. Walaupun terdapat kekurangtepatan terjemahan tetapi tidak merubah isi pesan dalam TSa.

Berdasarkan analisis pergeseran bentuk kelas kata pada data (2), diketahui bahwa makna kata "koufukuna" dan kata "bahagia" tidak terjadi pergeseran makna. Hal tersebut dapat diketahui berdasarkan tabel berikut ini.

Tabel 2 Analisis Komponen Makna Kata Koufukuna dan Bahagia

\begin{tabular}{llcc}
\hline No & \multicolumn{1}{c}{ Makna } & Koufukuna & Bahagia \\
\hline 1. & $\begin{array}{l}\text { Bebas dari } \\
\text { segala }\end{array}$ & & \\
& $\begin{array}{l}\text { yang } \\
\text { menyusah- }\end{array}$ & + & + \\
& & \\
kan & $\begin{array}{l}\text { Perasaan- } \\
\text { puas }\end{array}$ & + & + \\
\hline
\end{tabular}




\begin{tabular}{llll}
\hline 3. & $\begin{array}{l}\text { Keberuntu- } \\
\text { ngan }\end{array}$ & + \\
\hline
\end{tabular}

Berdasarkan tabel 2, komponen makna yang terkandung dalam kata koufukuna terdapat pada terjemahannya, yaitu bahagia. Kedua kata tersebut merupakan perasaan yang sangat bebas, puas, senang dan beruntung akibat mendapat atau merasakan suatu hal. Oleh karena itu penerjemahan kata koufukuna menjadi kata bahagia tidak mengalami pergeseran makna.

\subsection{Pergeseran Kelas Kata Adverbia (Fukushi) Menjadi Adjektiva}

(3) TSt

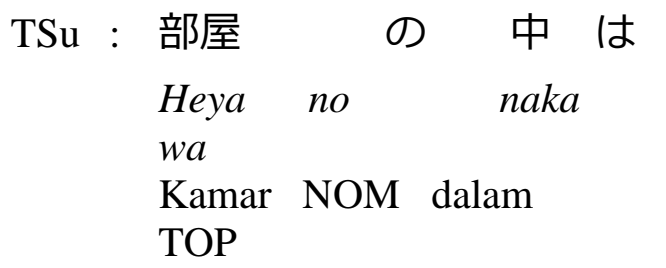

その せいか 急 に sono seika kyuuni itu rumah orangtua tibatiba

ひつそり なった もの です。

$\frac{\text { Hissori }}{\text { desu. }}$ natta mono
$\frac{\text { sepi }}{\text { KOP. }}$

(Kappa, 2007:120)

Tsa : Kamar tiba-tiba menjadi sepi.

(Kappa, 2016:59)

Pada data (3), kata "hissori" termasuk ke dalam kelas kata adverbia karena memiliki ciri-ciri yaitu tidak dapat menjadi subjek, predikat dan pelengkap dalam sebuah kalimat namun dapat menjadi kata yang menerangkan adverbia lain yaitu kyuuni serta berfungsi menyatakan suatu keadaan. Kelas kata yang mengalami pergeseran bentuk menjadi kelas kata adjektiva terletak di akhir kalimat yaitu kata "hissori" yang dipadankan dengan kata "sepi" dalam TSa. Kata "hissori" memiliki arti yaitu "sepi" (Matsuura, 2014:289). Sedangkan dalam bahasa Jepang kata hissori diartikan adalah sebagai berikut.

1. 物音や人声がせず静かなさま。

2. 静かに、目立ためようにするさま。

1. Monooto ya hitogoe ga sezu shizukana sama.

2. Shizukani, medatanu you ni suru sama.

(http://kotobank.jp/word/ひつそり)

1. Diam tanpa suara (alat) atau suara manusia.

2. Terdengar pelan, seperti tidak diketahui.

Kata "sepi" memiliki arti yaitu 'sunyi, lengang; tidak ada orang (kendaraan dan sebagainya), tidak ada kegiatan, tidak ada apa-apa, tidak ramai; tidak dihiraukan sama sekali' (Alwi dkk, 2005:1043). Kata "sepi" termasuk ke dalam kelas kata adjektiva karena ditandai oleh kemungkinannya untuk bergabung dengan partikel tidak, mendampingi nomina, atau didampingi partikel seperti lebih, sangat, agak serta dapat memperjelas sebuah situasi yaitu kamar yang tidak ada suara atau kegiatan apapun di dalamnya. Kalimat di atas diterjemahkan oleh penerjemah menggunakan teknik reduksi. Hal ini ditunjukkan dengan memadatkan informasi yaitu "heya no naka" menjadi 'kamar' dalam TSa. Namun demikian, hal ini tidak mengubah isi pesan secara keseluruhan dan terjemahan tersebut berterima dalam bahasa Indonesia.

Berdasarkan analisis pergeseran bentuk kelas kata pada data (3), diketahui bahwa makna kata "hissori" dan kata "sepi" tidak terjadi pergeseran makna, 
yaitu dapat dilihat berdasarkan tabel berikut ini.

Tabel 3 Analisis Komponen Makna kata Hissori dan Sepi

\begin{tabular}{llcc}
\hline No & \multicolumn{1}{c}{ Makna } & Hissori & Sepi \\
\hline 1. & Tidak ramai & + & + \\
2. & $\begin{array}{l}\text { Terdengar } \\
\text { pelan }\end{array}$ & + & + \\
3. & $\begin{array}{l}\text { Sunyi } \\
\text { 4. }\end{array}$ & + & + \\
& Tidak ada & + & + \\
\hline
\end{tabular}

Berdasarkan tabel 3, komponen makna 'tidak ramai', 'terdengar pelan', 'sunyi' yang terkandung dalam kata hissori terdapat pada terjemahannya yaitu sepi. Namun pada komponen makna 'tidak ada kegiatan' pada kata hissori memiliki tanda (-). Hal ini dikarenakan pada kata hissori, makna 'tidak ada kegiatan' berarti sebuah kondisi yang memperlihatkan bahwa tidak ada seorangpun dan tidak terjadi suatu aktifitas apapun, sedangkan kata sepi berarti ada seseorang yang jumlahnya sangat sedikit, melakukan aktifitas dengan kondisi yang sangat sunyi. Oleh karena itu, penerjemahan kata hissori menjadi sepi tidak terjadi pergeseran makna.

\subsection{Pergeseran Kelas Kata Nomina (Meishi) Menjadi Verba}

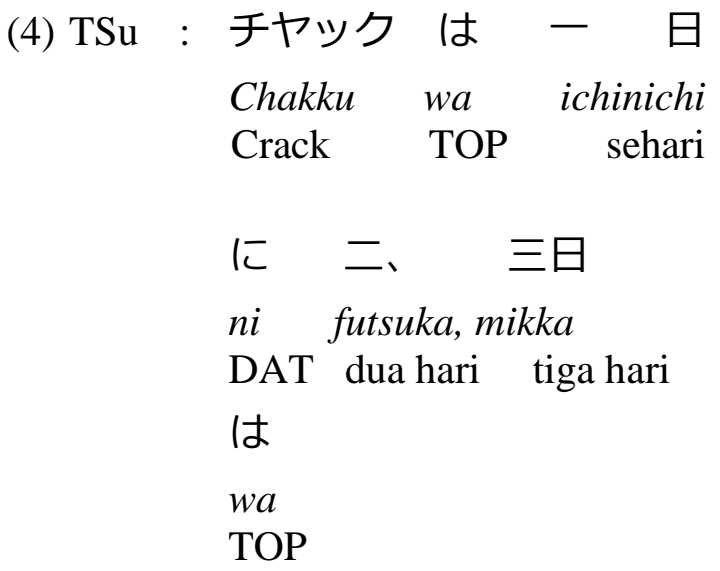

$\begin{array}{llr}\text { 必ず } & \text { 僕 } & \text { を } \\ \text { Kanarazu } & \text { boku } & \text { wo }\end{array}$

$$
\text { pasti }
$$$$
\text { saya AKU }
$$

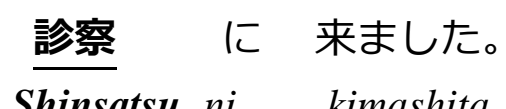

Shinsatsu ni kimashita. memeriksa DAT datang B.Lam

(Kappa, 2007:70)

TSa : Setiap hari Chack datang melihatku, dua atau bahkan tiga kali.

(Kappa, 2016:10)

Pada data (4), kata "shinsatsu" termasuk kategori kelas kata nomina karena ditandai dengan tidak dapat mengalami konjugasi serta dapat menyatakan sebuah kejadian atau peristiwa. Kelas kata yang mengalami pergeseran bentuk dari kelas kata nomina menjadi kelas kata verba terletak diakhirkalimat yaitu kata "shinsatsu" yang dipadankan dengan kata "melihat" dalam TSa. Kata "shinsatsu" memiliki arti yaitu 'pemeriksaan' (Matsuura, 2014:929). (Matsumura, 1992:609) mengartikan kata shinsatsu sebagai berikut.

医者が患者のからだをしらべ、病

\section{気・病状を判断すること。}

Isha ga kanja no karada wo shirabe, byouki to byoujou wo handan suru koto.

Dokter memeriksa badan pasien, dan menyimpulkan sakit dan penyakit pasien.

Kata "melihat" memiliki arti yaitu 'menggunakan mata untuk memandang (memperhatikan); menonton; menilik; menengok (orang sakit); menjenguk' (Alwi dkk, 2005:670). Kata "melihat" termasuk ke dalam kelas kata verba karena dapat didampingi partikel tidak dan tidak dapat didampingi partikel di, ke, dari, atau dengan partikel seperti sangat, lebih, atau agakserta dapat menjelaskan suatu aktifitas atau tindakan seseorang. Kalimat di atas diterjemahkan oleh penerjemah menggunakan teknik penerjemahan harfiah yaitu dengan 
menerjemahkan kata per kata tanpa mengubah isi pesan dalam TSu sehingga pembaca dapat memahami konteks kalimat secara keseluruhan.

Berdasarkan analisis pergeseran bentuk kelas kata pada data (4), diketahui bahwa makna kata "shinsatsu" dan kata "melihat" terjadi pergeseran makna. Hal tersebut dapat dibuktikan melalui tabel berikut ini.

Tabel 4 Analisis Komponen Makna kata Shinsatsu dan Melihat

\begin{tabular}{|c|c|c|c|}
\hline No & Makna & Shinsatsu & Melihat \\
\hline 1. & $\begin{array}{l}\text { Pemeri- } \\
\text { ksaan }\end{array}$ & + & - \\
\hline 2. & $\begin{array}{l}\text { Menggu } \\
\text { nakan } \\
\text { mata } \\
\text { untuk } \\
\text { meman- } \\
\text { dang }\end{array}$ & \pm & + \\
\hline 3. & $\begin{array}{l}\text { Dokter } \\
\text { memer- } \\
\text { iksa dan } \\
\text { menyim- } \\
\text { pulkan } \\
\text { penyakit } \\
\text { pasien }\end{array}$ & + & - \\
\hline 4. & $\begin{array}{l}\text { Menon- } \\
\text { ton }\end{array}$ & - & + \\
\hline
\end{tabular}

komponen makna di atas, komponen makna 'pemeriksaan' dan 'dokter memeriksa dan menyimpulkan penyakit pasien' pada kata melihat memiliki tanda (-). Hal tersebut karena kedua makna tersebut merupakan suatu tindakan medis yang dilakukan seorang petugas medis dan tidak dilakukan oleh sembarang orang bukan sekadar melihat dengan indera pengelihatan. Kemudian pada komponen makna 'menonton' pada kata shinsatsu memiliki tanda (-) yang jika diartikan ke dalam bahasa Indonesia menonton berarti menggunakan mata untuk memandang yang tidak memerlukan keahlian khusus.
Pergeseran makna pada kata
"shinsatsu" menyebabkan berkurangnya isi pesan yang terdapat dalam teks. Penggunaan kata "melihat" dalam kalimat tersebut menyebabkan timbulnya kesalahan penafsiran oleh pembaca. Kata "shinsatsu" sebaiknya dapat diterjemahkan sebagai kata 'memeriksa' yang memiliki arti 'melihat dengan teliti untuk mengetahui keadaan (baik tidaknya, salah benarnya, dan sebagainya); menyelidiki untuk mengetahui sesuatu (untuk mempelajari, mencari pengetahuan, dan sebagainya); menelaah (suatu hal, peristiwa, dsb)' (Alwi dkk, 2005:858).

\section{Simpulan}

Berdasarkan hasil analisis yang telah dilakukan dari cerpen Kappa karya Akutagawa Ryunosuke dalam bahasa Jepang sebagai TSu serta dalam bahasa Indonesia sebagai TSa, dapat disimpulkan bahwa pergeseran bentuk kelas kata terjadi karena perbedaan struktur BSu dan BSa. Hal ini dilakukan, karena pada saat penerjemah menerjemahkan suatu teks dari BSu ke dalam BSa. Beberapa kata yang kurang tepat jika diterjemahkan begitu saja dan jika tetap digunakan, pembaca kurang memahami isi teks tersebut. Oleh karena itu, penerjemah lebih memilih menggunakan kata lain untuk hasil terjemahan yang dapat diterima dan dipahami pembaca.

\section{Daftar Pustaka}

Akutagawa, Ryunosuke. 2016. Kappa. Jakarta: KPG (Kepustakaan Populer Gramedia)

Akutagawa, Ryunosuke. 2007. Kappa. Tokyo: Shueisha Co., Ltd

Alwi, Hasan. 2005. Kamus Besar Bahasa Indonesia Edisi Ketiga. Jakarta: Balai 
Pustaka

Catford, J.C. 1965. A Linguistic Theory of Translation : An Essay in Applied Linguistics. Oxford : Oxford University Press

Matsumura, Makoto. dkk. 1992. Kokugo Daijiten. Japan: Oubunsha

Matsuura, Kenji. 2014. Kamus JepangIndonesia. Jakarta: PT. Gramedia Pustaka Utama

Molina, Lucia and Hurtado Albir, A. 2002. "Translation Techniques Revisited: A Dynamic and Functionalist Approach" dalam Meta: Journal des Traducteur/Meta: Translators" Journal. XLVII, No.4 hal. 498-512

Nida, Eugene A. and Charles R. Taber. 1969. The Theory and Practice of Translation. Leiden : E.J. Brill

Simatupang, Maurit, D.S. 1999. Pengantar Teori Penerjemahan. Jakarta: Depdiknas

Sunagawa, Yuriko. 2005. Nihongo Bunkei Jiten. Tokyo: Kurosio Publishers 